\title{
A new species of Lachesana Strand, 1932 (Aranei: Zodariidae) from Southern Kazakhstan
}

\author{
Новый вид рода Lachesana Strand, 1932 (Aranei: Zodariidae) \\ из Южкного Казахстана
}

\author{
Alexander A. Fomichev', Yuri M. Marusik ${ }^{2,3}$ \\ А.А. Фомичев ${ }^{1}$, Ю.М. Марусик ${ }^{2,3}$
}

\footnotetext{
${ }^{1}$ Altai State University, Lenina Pr., 61, Barnaul, RF-656049, Russia. E-mail: a.fomichov@mail.ru

${ }^{1}$ Алтайский государственный университет, просп. Ленина, 61, Барнаул, 656049, Россия.

${ }^{2}$ Institute for Biological Problems of the North RAS, Portovaya Str. 18, Magadan, 685000 Russia. E-mail: yurmar@mail.ru

${ }^{2}$ Институт биологических проблем Севера ДВО РАН, Портовая 18, Магадан, 685000 Россия.

${ }^{3}$ Department of Zoology \& Entomology, University of the Free State, Bloemfontein 9300, South Africa.
}

KEY WORDS: Ant-eating spiders, Araneae, Central Asia, Lachesaninae, new species.

КЛЮЧЕВЫЕ СЛОВА: Пауки-муравьеды, Araneae, Центральная Азия, Lachesaninae, новый вид.

ABSTRACT. A new species Lachesana dyachkovi sp.n. is described from Southern Kazakhstan based on a single male. The new species is related to L. tarabaevi Zonstein et Ovtchinnikov, 1999 and differs from it by the shape of the male palp, strongly modified cheliceral fang, leg spination and smaller body size.

How to cite this article: Fomichev A.A., Marusik Yu.M. 2019. A new species of Lachesana Strand, 1932 (Aranei: Zodariidae) from Southern Kazakhstan // Arthropoda Selecta. Vol.28. No.4. P.556-561. doi: 10.15298/arthsel. 28.4.08

РЕЗЮМЕ. Из Южного Казахстана по единственному самцу описан новый вид пауков Lachesana dyachkovi sp.n. Новый вид близок к L. tarabaevi Zonstein et Ovtchinnikov, 1999, но отличается от него строением пальпы самца, сильно модифицированными коготками хелицер, шипованием ног и размерами тела.

\section{Introduction}

Zodariidae Thorell, 1881 is a medium-sized family comprising 1166 species placed in 86 genera and five subfamilies [Jocqué, Dippenaar-Schoeman, 2006; World Spider Catalog, 2019]. The family is distributed in tropical and subtropical regions of all continents, but only a few genera are found in the Palaearctic [Jocqué, Dippenaar-Schoeman, 2006]. Zodariidae exhibit an extremely high degree of morphological and ecological diversity, including free-living ground-dwellers, burrowing and tree-living forms [Jocqué, 1991; Jocqué, Dippenaar-Schoeman, 2006]. Spiders of this family have a diet consisting of ants and termites; moreover, different species of Zodariidae are specialized in hunting different species of ants [Marusik, Kovblyuk, 2011]. So far, only two subfamilies of Zodariidae are known from Central Asia, Zodariinae Thorell, 1881 and Lachesaninae Jocqué, 1991. The latter subfamily is represented by a single genus and species in the region, Lachesana tarabaevi Zonstein et Ovtchinnikov, 1999 [Mikhailov, 2013]. This species is reported from Kazakhstan, Kyrgyzstan, Tajikistan and Uzbekistan [Zonstein, Ovtchinnikov, 1999]. One of the paratypes of $L$. tarabaevi was collected in Southern Kazakhstan, but it is represented by a juvenile specimen, providing little confidence in its identification.

While studying material from Southern Kazakhstan, we found one male belonging to Lachesana. This male was later found to differ from $L$. tarabaevi and other congeners, and thus considered to represent an undescribed species. The goals of this paper are to provide both a detailed description of the new species and morphological notes of the genus.

\section{Material and methods}

Specimens were photographed using an Olympus DP74 camera attached to an Olympus SZX16 stereomicroscope at the Altai State University. Photographs were taken in dishes with white paraffin on the bottom and filled with alcohol. Digital images were montaged using Helicon Focus software (https://www.photosoft.ru/helicon-focus/). All measurements are in millimeters. Type material will be deposited in the Institute of Systematics and Ecology of Animals, SB RAS, Novosibirsk, Russia (ISEA).

Abbreviations

Leg segments: Fe — femur, $\mathrm{Pt}$ - patella, Mt — metatarsus, $\mathrm{Ti}$ - tibia, $\mathrm{Ta}$ - tarsus.

Spination: $\mathrm{d}$ - dorsal, $\mathrm{p}$ - prolateral, $\mathrm{r}$ - retrolateral, $\mathrm{v}$ - ventral.

Eyes: ALE - anterior lateral eyes, AME - anterior median eyes, MOA - median ocular area, MOA-L — length 


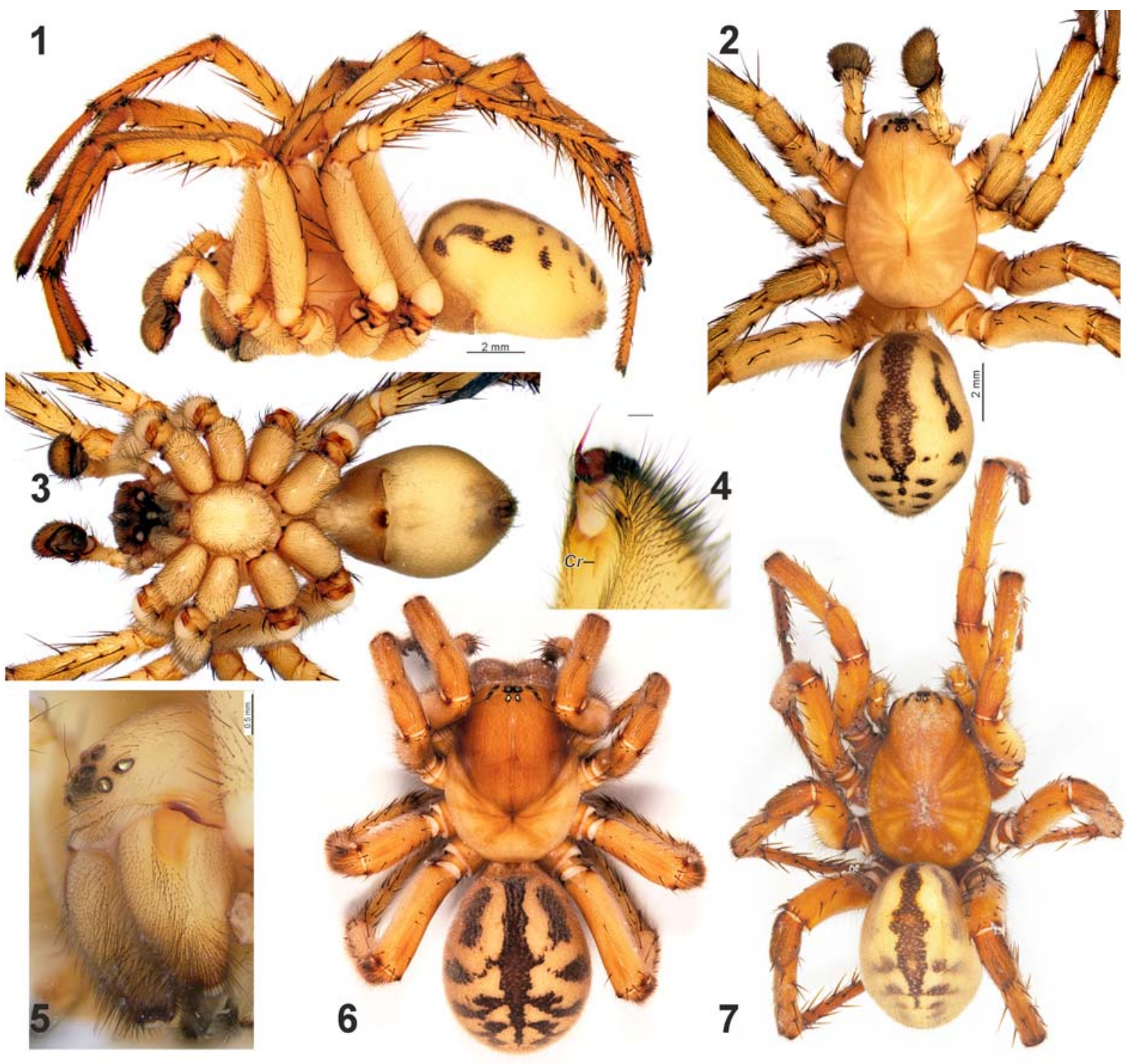

Figs 1-7. Habitus, chelicera and cephalic part of Lachesana dyachkovi sp.n. (1-5) and L. tarabaevi (6-7). 1 - lateral; 2, 6-7 dorsal; 3 - ventral; 4 - mesal; 5 - anterolateral. Scale bars: $1-2=2 \mathrm{~mm}, 4=0.2 \mathrm{~mm}, 5=0.5 \mathrm{~mm}$. Figs $6-7-$ courtesy of S.L. Zonstein.

Рис. 1-7. Внешний вид, хелицера и головная часть Lachesana dyachkovi sp.n. (1-5) и L. tarabaevi (6-7). 1 - сбоку; 2, 6-7 дорзально; 3 - вентрально; 4 - мезиально; 5 - переднебоковой вид. Масштабные линейки: $1-2=2$ мм, $4=0,2$ мм, $5=0,5$ мм. Рис. 6-7 предоставлены С.Л. Зонштейном.

of MOA, MOA-WA — anterior width of MOA, MOA-WP posterior width of MOA, PLE — posterior lateral eyes, PME - posterior median eyes.

\section{Taxonomic survey}

\section{Lachesana Strand, 1932}

Lachesis Savigny et Audouin, 1825: 110.

Lestes Gistel, 1848: IX (nom.n. pro Lachesis).

Laches Thorell, 1869: 37 (nom.n. pro Lestes).

Lachesana Stand, 1932: 140 (nom.n. pro Laches); Levy, 1990: 329; Jocqué, 1991: 34

TYPE SPECIES. Lachesis perversa Savigny et Audouin, 1827 from Egypt.
DIAGNOSIS. Both sexes of this genus are well differentiated from other Palaearctic Zodariidae by numerous spines on all legs (>40/leg). Males of Lachesana can be recognized by the recurved cheliceral fangs and hollowed-out tibial apophysis. Females belonging to this genus differ by a flat epigyne lacking the median plate; long and retractable anterior spinnerets, unmodified eye positions and maxillae with a baso-lateral extension [Jocqué, 1991].

COMPOSITION AND DISTRIBUTION. The genus comprises eight named species including the new one: $L$. blackwalli (O. Pickard-Cambridge, 1872) (Mediterranean), L. dyachkovi sp.n. (South Kazakhstan), L. graeca Thaler et Knoflach, 2004 (Greece), L. insensibilis Jocqué, 1991 (Near East), L. perversa (Audouin, 1826) (Near East), L. rufiventris (Simon, 1873) (Near East), L. tarabaevi Zonstein et 

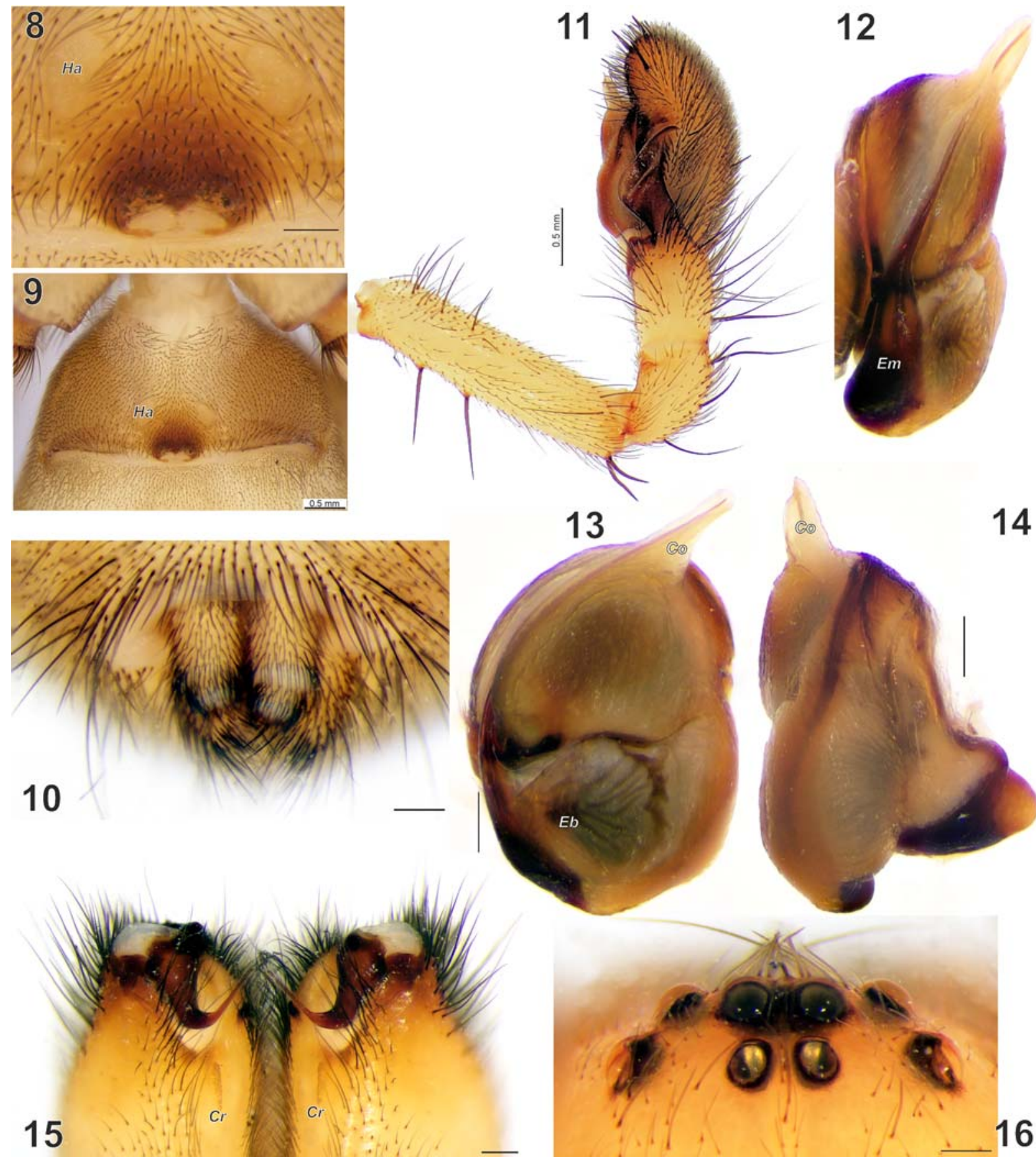

16

Fig 8-16. Epiandrus (8), book lungs (9), spinnerets (10), male palp (11), bulb (12-14), chelicerae (15) and eyes (16) of Lachesana dyachkovi sp.n. $8-10,13$ - ventral; 11, 14 - retrolateral; 12 - prolateral, 15 - posterior; 16 - dorsal. Scale bars: $8=0.1 \mathrm{~mm}, 9,11=$ $0.5 \mathrm{~mm}, 10,13-16=0.2 \mathrm{~mm}$.

Abbreviations: $\mathrm{Co}-$ conductor, $\mathrm{Cr}-$ row of pigment dots of cheliceral groove; $\mathrm{Eb}-$ base of embolus, $\mathrm{Em}-$ embolus, $\mathrm{Ha}-$ hairless areas of the epigaster.

Рис. 8-16. Эпиандрус (8), лёгочные книжки (9), паутинные бородавки (10), пальпа самца (11), бульбус (12-14), хелицеры (15) и глаза (16) Lachesana dyachkovi sp.n. 8-10, 13 - вентрально; 11, 14 - ретролатерально; 12 - пролатерально; 15 - сзади; 16 дорзально. Масштабные линейки: $8=0,1$ мм, $9,11=0,5$ мм, 10, 13-16 =0,2 мм.

Сокращения: $C o-$ кондуктор, $C r-$ ряд пигментных точек бороздки хелицер, $E b-$ основание эмболюса, $E m-$ эмболюс, $H a-$ безволосые участки эпигастральной области. 
Ovtchinnikov, 1999 (Central Asia) and L. vittata (Strand, 1906) (Tunisia).

COMMENT. Within the genus, structures of the bulb are nearly indistinguishable, but different species can be separated by the shape of the retrolateral tibial apophysis.

Lachesana dyachkovi sp.n.

Figs 1-5, 8-16, 17-19, 22, 26-27.

Lachesana tarabaevi Zonstein et Ovtchinnikov, 1999: 59, f. 1-5 ( $\sigma^{7}+$, in part, juvenile specimen from Kazakhstan).

TYPES. KAZAKHSTAN: Turkistan Region: holotype ${ }^{\prime}$ (ISEA) Bel'tau Mountains, N41 '50'09.9', E68 32'15.4", residua mountains in steppe, 392 m, 8-9.06.2017 (Yu.V. Dyachkov).

ETYMOLOGY. The specific name is a patronym in honour of Yuri V. Dyachkov (Barnaul, Russia), myriapodologist and friend of the first author, who has provided rich spider material from Southern Kazakhstan, including the type of the new species.

DIAGNOSIS. Lachesana dyachkovi sp.n. differs from the similar Central Asian species L. tarabaevi by having strongly modified cheliceral fangs bent $>90^{\circ}$ (vs. almost unmodified, bent only at tip), carapace lacking pattern (vs. present), relatively shorter tibial apophysis (cf. Figs 22-23) with distal part as wide as tibia (vs. distal part longer than tibia width) and also by size: 13.7 total length and 6.7 carapace length vs. 15-22 total length and carapace length 7.93-9.05 in L. tarabaevi. Holotypes of the two species differ by the number of spines, especially on leg I, 55 in the new species and 81 in L. tarabaevi and also the leg formula is 4312 in L. dyachkovi sp.n. vs. 4132. In addition, the two species can be separated by the size and interdistances of hairless areas $(\mathrm{Ha})$ on the epigaster: separated by 3 diameters in the new species and 2 diameters in L. tarabaevi.

DESCRIPTION. Male (holotype). Total length 13.7. Carapace: 6.7 long, 4.5 wide. Eye measurements: AME: 0.19, ALE: 0.23, PME: 0.19, PLE: 0.23, AME-AME: 0.13, AME-PME: 0.09, PME-PME: 0.13, MOA-L: 0.44, MOAWA: 0.5, MOA-WP: 0.43. Prosoma and all limbs yellow. Carapace without pattern. Chelicera with modified fang, fang bent $>90^{\circ}$, groove with short row of pigment dots of $(\mathrm{Cr})$. Chelicera with 2 promarginal teeth, one large and a smaller one. Abdomen and spinnerets yellow. Abdomen with gray cardiac mark and four longitudinal rows of gray spots. Book-lung opercula with indistinct margins, covered with the same type of setae as other parts of the epigaster except the epiandrus. Epiandral area dark brown, distinct, covered with setae shorter than that on the rest of epigaster; epigaster with a pair of hairless (lacking setae) areas $(\mathrm{Ha})$ anterior to epiandrus. Legs with numerous spines, from 55 to 81 .

Leg measurements:

$\begin{array}{lcccccc} & \text { Fe } & \text { Pt } & \text { Ti } & \text { Mt } & \text { Ta } & \text { Total } \\ \text { Palp } & 2.5 & 1.0 & 0.85 & - & 1.8 & 6.15 \\ \text { I } & 5.75 & 2.35 & 4.5 & 4.6 & 3.2 & 20.4 \\ \text { II } & 5.5 & 2.25 & 3.95 & 4.9 & 3.35 & 19.95 \\ \text { III } & 5.55 & 2.3 & 3.4 & 6.25 & 3.3 & 20.8 \\ \text { IV } & 6.55 & 2.5 & 4.3 & 8.05 & 3.75 & 25.15\end{array}$

Leg spination:

$\begin{array}{llll}\mathrm{Fe} & \mathrm{Pt} & \mathrm{Ti} & \mathrm{Mt}\end{array}$

$\begin{array}{llllll}\mathrm{I} & \mathrm{d} 7 \mathrm{p} 5 \mathrm{r} 5 & \mathrm{p} 1 & \mathrm{p} 6 \mathrm{r} 2 \mathrm{v} 7 & \mathrm{p} 4 \mathrm{r} 2 \mathrm{v} 16 \quad 55\end{array}$

II $\begin{array}{lllll}\mathrm{d} 5 \mathrm{p} 4 \mathrm{r} 4 & \mathrm{p} 2 & \mathrm{p} 4 \mathrm{r} 2 \mathrm{v} 9 & \mathrm{p} 7 \mathrm{r} 5 \mathrm{v} 17 & 59\end{array}$

III $\quad \mathrm{d} 5 \mathrm{p} 4 \mathrm{r} 4$ d1 $\mathrm{p} 2 \mathrm{r} 1 \quad \mathrm{~d} 3 \mathrm{p} 5 \mathrm{r} 4 \mathrm{v} 9 \quad \mathrm{~d} 7 \mathrm{p} 8 \mathrm{r} 3 \mathrm{v} 22 \quad 78$

IV d6 p4 r5 d1 p2 r1 d3 p5 r5 v7 d6 p7 r7 v22 81

Palp as in Figs 11-14, 17-19, 22; femur long, almost as long as tibia+cymbium, 4 times longer than wide; patella and tibia of equal length; tibia with long apophysis, tibia together with apophysis as long as cymbium, anterior part of apophysis as long as tibia width; cymbium about 1.8 times longer than wide, covered with both normal and sparse spine-like setae; bulb elongate, 1.3 times longer than wide; base of embolus $(E b)$ large, $1 / 2$ of the tegular length, covered with transverse wrinkles; embolus filamentous, lying in chute formed by conductor, obscured on undissected bulb.

Female unknown.

BIOLOGY. Almost nothing is known about the biology of the new species. Like all other known species of Lachesa$n a$, the new species was collected in an arid habitat (Fig. 27). By analogy with other species of the genus it can be assumed that females of L. dyachkovi sp.n. live in deep burrows and are difficult to collect, while males are freeliving, wandering.

DISTRIBUTION (Fig. 26). Reliably known only from the type locality. The record of $L$. tarabaevi by Zonstein et Ovtchinnikov [1999] from the Karatau Mountains in Southern Kazakhstan is based on a juvenile specimen. Logunov et al. [2012] in the popular book 'Spiders of Kazakhstan' provide data that L. tarabaevi dwells in semidesert habitats of the southern foothills of the Karatau Mountain Range. The Karatau Mountain Range is close to the type locality of L. dyachkovi sp.n. (about $150 \mathrm{~km}$ ), and we consider records of L. tarabaevi from this area refer to L. dyachkovi sp.n.

Lachesana tarabaevi Zonstein et Ovtchinnikov, 1999 Figs 6-7, 20-21, 23-25, 26.

Lachesana tarabaevi Zonstein et Ovtchinnikov, 1999: 59, f. 1-5 ( $\sigma^{\top}$ \% , in part, juvenile specimen from Kazakhstan belongs to $L$. dyachkovi sp.n.).

MATERIAL EXAMINED. Photographs of paratypes collected together with the holotype male Kyrgyzstan, $1.5 \mathrm{~km}$ E of DzhalalAbad foothills of Ferghansky Mt. Range, $40^{\circ} 56^{\prime} \mathrm{N} 73^{\circ} 02^{\prime} \mathrm{E}$, South Kyrgyzstan, 11-21.03.1994 (S.V. Ovtchinnikov, S.L. Zonstein).

DIAGNOSIS. See diagnosis for L. dyachkovi sp.n.

DESCRIPTION. See Zonstein \& Ovtchinnikov [1999]. Spination (total number of spines in the holotype): I 81, II 61, III 79, IV 84.

NOTES. The description of the male holotype of $L$. tarabaevi is lacking a description of the cheliceral fang which is different from all other species (Zonstein et Kunt, pers. comm.) of the genus in being almost unmodified with a slightly bent tip only. The description also lacks details about the setae covering the anterior part of the chelicera. Males of L. tarabaevi have a small in size clusters of strong setae near the base of the fang. In the new species, setae are weaker and are not clustered but evenly spread on the terminal part of the chelicera. Hairless areas on the epigaster are large and separated by about 2 diameters (Zonstein, pers. comm.). Cheliceral groove of this species also has a row of pigmented dots as shown in Fig. 15.

DISTRIBUTION (Fig. 26). This species was described based on specimens from Kyrgyzstan, eastern Uzbekistan, western Tajikistan and southern Kazakhstan. The Kazakh record is based on a juvenile specimen and refers to $L$. dyachkovi sp.n.

\section{Discussion}

While studying new species we noticed the presence of hairless areas $(\mathrm{Ha})$ on the epigaster, completely free of setae anterior to the epiandrus. The size of this area differs in the new species and L. graeca Tha- 

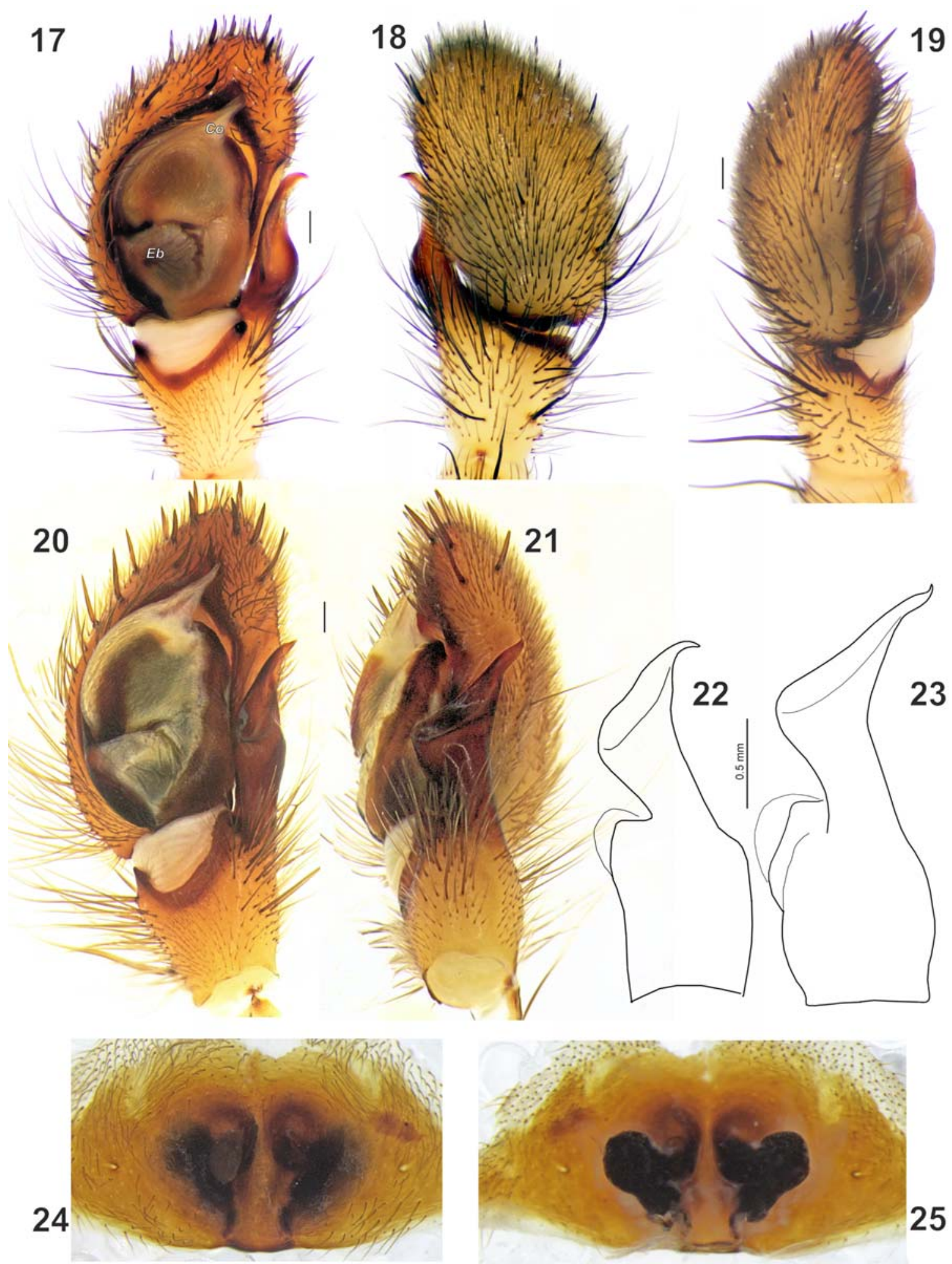

Fig 17-25. Male palp (17-23) and epigyne (24-25) of Lachesana dyachkovi sp.n. (17-19, 22) and L. tarabaevi (20-21, 23-25). 17, 20, 24 - ventral; 18,25 - dorsal; 19 - prolateral; $21-23$ - retrolateral. Figs $20-21,24-25$ - courtesy of S.L. Zonstein. Scale bars: $17-$ $21=0.2 \mathrm{~mm}, 22-23=0.5 \mathrm{~mm}$.

Abbreviations: $E b$ - base of embolus, $C o$ - conductor.

Рис. 17-25. Пальпа самца (17-23) и эпигина (24-25) Lachesana dyachkovi sp.n. (17-19, 22) и L. tarabaevi $(20-21,23-25)$. 17, 20, 24 - вентрально; 18, 25 - дорзально; 19 - пролатерально; 21-23 - ретролатерально. Рис. 20-21, 24-25 - предоставлены С.Л. Зонштейном. Масштабные линейки: $17-19=0,2$ мм, 22-23 = 0,5 мм.

Сокращения: $E b-$ основание эмболюса, $C o-$ кондуктор. 


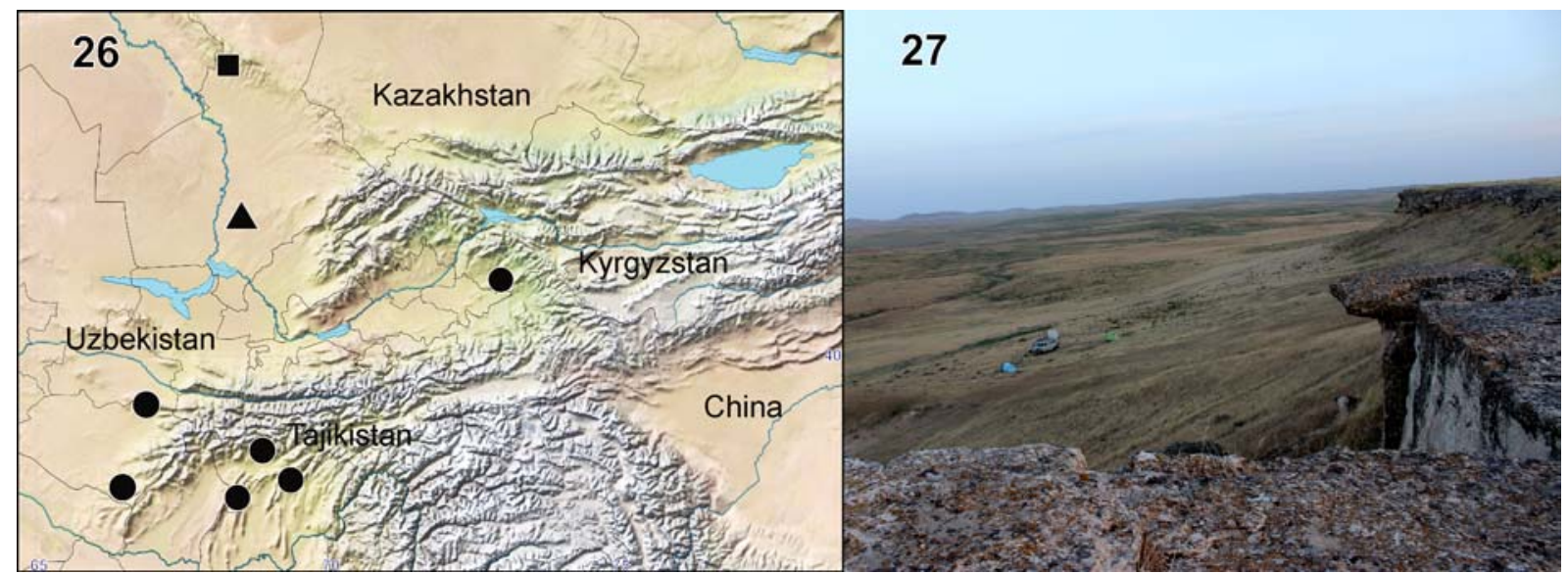

Fig 26-27. Collecting localities of Lachesana species in Central Asia (26) and habitat of L. dyachkovi sp.n. (27). L. dyachkovi sp.n. triangle; L. tarabaevi - circle; record of L. tarabaevi in Kazakhstan, based on a juvenile specimen, refers to L. dyachkovi sp.n. — square.

Рис. 26-27. Находки видов Lachesana в Центральной Азии (26) и биотоп L. dyachkovi sp.n. (27). L. dyachkovi sp.n. — треугольник; L. tarabaevi - круг; находка ювенильного экземпляра L. tarabaevi в Казахстане, возможно, принадлежащего к виду L. dyachkovi sp.n. — квадрат

ler et Knoflach, 2004 (cf. Fig. 8 and fig. 6 in Thaler \& Knoflach [2004]) as well as in L. dyachkovi sp.n. and L. tarabaevi. The latter species has larger hairless areas separated by 2 diameters. One of the most characteristic features of the genus, a modified (strongly bent) fang of the male chelicera has been found in all species including the new species, with exception of $L$. tarabaevi (only tip of the fang is slightly bent). In most spiders, leg formula is stable within the genus or even family, but in Lachesana there were at least four different formulae: 4123, 4321 [Jocqué, 1991], 4132 in $L$. tarabaevi and 4312 in L. dyachkovi sp.n.

It is likely that the species diversity of Lachesana in Central Asia is greater than two. Sergei Zonstein (pers. comm.) mentioned that he saw very large specimens, larger than L. tarabaevi, among material from Badkhyz (southeastern Turkmenistan) in the collection of the Zoological Institute in St-Petersburg. Unfortunately, these specimens cannot be located at this time (Nekhaeva, pers. comm.).

\section{Acknowledgements}

We thank Yuri V. Dyachkov (Barnaul, Russia) for collecting the material treated here, Sergei L. Zonstein (TelAviv, Israel) and Kadir B. Kunt (Ankara, Turkey) for providing comparative figures of the paratypes of $L$. tarabaevi and information about this species. We also thank Anna A. Nekhaeva and Kirill G. Mikhailov (Moscow, Russia) for help in searching for Lachesana specimens in the collection of the Zoological Institute (St-Petersburg) and Zoological Museum (Moscow) respectively. The English of the final draft was kindly checked by Sarah Crews (San Francisco, USA).

\section{References}

Gistel J. 1848. Naturgeschichte des Thierreichs für höhere Schulen. Stuttgart. $\mathrm{xvi}+220 \mathrm{~S}$.

Jocqué R. 1991. A generic revision of the spider family Zodariidae (Araneae) // Bulletin of the American Museum of Natural History. Vol.201. P.1-160.

Jocqué R., Dippenaar-Schoeman A.S. 2006. Spider families of the World. Musée Royal de l'Afrique Central Tervuren. 336 pp.

Levy G. 1990. Spiders of the genus Lachesana and a new storenoid genus from Israel (Araneae: Zodariidae) // Zoological Journal of the Linnean Society. Vol.98. P.327-362.

Logunov D.V., Gromov A.V., Timokhanov V.A. 2012. Spiders of Kazakhstan. Manchester, UK: Siri Scientific Press. 232 pp.

Marusik Yu.M., Kovblyuk M.M. 2011. [Spiders (Arachnida, Aranei) of Siberia and Russian Far East]. Moscow: KMK Scientific Press. 344 pp. [In Russian]

Mikhailov K.G. 2013. The spiders (Arachnida: Aranei) of Russia and adjacent countries: a non-annoteted cheklist. Arthropoda Selecta. Supplement No.3. 262 pp.

Savigny J-C., Audouin V. 1826. Explication sommaire des planches d'arachnides de l'Égypte et de la Syrie // Description de l'Égypte, ou recueil des observations et des recherches qui ont été faites en Egypte pendant l'expédition de l'armée française, publié par les ordres de sa Majesté l'Empereur Napoléon le Grand. Histoire Naturelle. Vol.1. No.4. P.1-339.

Strand E. 1932. Miscellanea nomenclatorica zoologica et palaeontologica, III, IV // Folia Zoologica et Hydrobiologica, Rigā. Vol.4. P.133-147, 193-196.

Thorell T. 1869. On European spiders. Part I. Review of the European genera of spiders, preceded by some observations on zoological nomenclature // Nova Acta Regiae Societatis Scientiarum Upsaliensis. Vol.3. No.7. P.1-108.

World Spider Catalog. 2019. World Spider Catalog. Version 20.5. Natural History Museum Bern, online at http://wsc.nmbe.ch (accessed on September 2019).

Zonstein S.L., Ovtchinnikov S.V. 1999. A new Central Asian species of the spider genus Lachesana Strand, 1932 (Araneae, Zodariidae: Lachesaninae) // Tethys Entomological Research. Vol.1. P.59-62. 